\title{
Globe
}

Revue internationale d'études québécoises

\section{Un nouveau pluralisme}

\section{Daniel Chartier}

Volume 1, numéro 1, 1998

Raisons communes

URI : https://id.erudit.org/iderudit/1000098ar

DOI : https://doi.org/10.7202/1000098ar

Aller au sommaire du numéro

Éditeur(s)

Globe, Revue internationale d'études québécoises

ISSN

1481-5869 (imprimé)

1923-8231 (numérique)

Découvrir la revue

Citer ce document

Chartier, D. (1998). Un nouveau pluralisme. Globe, 1(1), 7-7. https://doi.org/10.7202/1000098ar d'utilisation que vous pouvez consulter en ligne.

https://apropos.erudit.org/fr/usagers/politique-dutilisation/ 


\section{Présentation du numéro Un nouveau pluralisme}

\section{Daniel Chartier}

Université de La Sarre

Notre premier numéro s'ouvre sur la pluralité civique et culturelle du Québec. La recherche de «raisons communes» qui puissent nous rassembler, comme le disait Fernand Dumont, révèle une fragmentation de l'identité qui est tributaire d'une diversité elle-même fondatrice de nouvelles appartenances. Pour Jocelyn MacLure, «les pérégrinations contemporaines de l'identité» obligent ̀̀ réarticuler les frontières de l'identité québécoise. Ses propositions répondent en quelque sorte à l'article posthume que nous a laissé Julien Harvey, l'un des pionniers du pluralisme culturel au Québec, qui écrit avec conviction que des arrivants ont droit à la ressemblance plus encore qu'à la différences. Dans une seconde partie, Jacques Beauchemin examine comment un nouvel argumentaire souverainiste pourrait arriver à justifier «da faisabilité et la légitimités de lindépendance québécoise, acquise dans un Québec profondément divisé. Enfin, François Rocher décrit comment le Québec pourrait établir une citoyenneté commune à tous ses habitants dans le cadre d'un Canada qui se voudrait multinational. 